\title{
Introduction of an isoxazoline unit to the $\beta$-position of porphyrin via regioselective 1,3-dipolar cycloaddition reaction
}

\author{
Xiujun Liu ${ }^{1,2}$, Xiang Ma ${ }^{* 1}$ and Yaqing Feng ${ }^{* 2,3}$
}

\section{Letter}

Address:

${ }^{1}$ Research Center of Analysis and Test, School of Chemistry and Molecular Engineering, East China University of Science \& Technology, Meilong Road 130, Shanghai 200237, China, ${ }^{2}$ School of Chemical Engineering and Technology, Tianjin University, Tianjin 300072, China and ${ }^{3}$ Collaborative Innovation Center of Chemical Science and Engineering, Tianjin 300072, China

\section{Email:}

Xiang Ma* - maxiang@ecust.edu.cn; Yaqing Feng ${ }^{*}$ -

yqfeng@tju.edu.cn

* Corresponding author

Keywords:

dipolar cycloaddition; isoxazoline; macrocycles; nitrile oxide; porphyrin
Beilstein J. Org. Chem. 2019, 15, 1434-1440.

doi:10.3762/bjoc. 15.143

Received: 26 April 2019

Accepted: 17 June 2019

Published: 28 June 2019

This article is part of the thematic issue "Novel macrocycles - and old ones doing new tricks".

Guest Editor: W. Jiang

(C) 2019 Liu et al.; licensee Beilstein-Institut.

License and terms: see end of document.

\begin{abstract}
Isoxazoline-linked porphyrins have been synthesized by a regioselective 1,3-dipolar cycloaddition reaction between vinylporphyrin 2 and nitrile oxides. The steric interaction directed the reaction trajectory, in which only the product with a link between the 5-position of the isoxazoline and the $\beta$-position of porphyrin was observed. The isoxazoline-porphyrins $\mathbf{3 a}, \mathbf{b}$ have been characterized by absorption, emission, ${ }^{1} \mathrm{H}$ NMR and mass spectra. Later, the crystal structure of $\mathbf{3 a}$ was obtained and confirmed the basic features of the NMR-derived structure. Furthermore, a pair of enantiomers of 3a presented in the crystal, which formed a dimeric complex through intermolecular coordination between the $\mathrm{Zn}^{2+}$ center and the carbonyl group of the second molecule.
\end{abstract}

\section{Introduction}

In nature, porphyrin-type compounds play a prominent role in life [1]. It is well known that certain vital functions, like $\mathrm{O}_{2}$ transport, photosynthesis etc. depend on the action of porphyrin-metal complexes [2-5]. Inspired by the natural porphyrinoids, some man-made porphyrinoids have been designed to mimic the characteristic functions with purposes of utilization in various fields (please see recent reviews [6-14]). In order to achieve application-oriented molecules, lots of modification approaches have been developed [15-24]. Among them, the 1,3dipolar cycloaddition reaction [25] is an efficient method to fuse five-membered rings on the periphery of the porphyrin framework. Because the periphery double bonds of the porphyrin macrocycle are nice dipolarophiles, and can trap 1,3-dipoles to furnish the chlorin or bacteriochlorin analogues [26-37]. On the other hand, the formed heterocycles are also very important. For example, isoxazoline derivatives are not only significant intermediates in organic synthesis, e.g., masked aldols [38,39], but also have a broad spectrum of interesting bioactivities, e.g., anti-inflammatory [40,41]. In addition, a few porphyrin-based dipoles have been also reported [42]. Recently, a 1,3-dipolar 
cycloaddition reaction was performed between the vinyl group at methyl pheophorbide A and the in-situ-generated nitrile oxide, which showed inferior selectivity and afforded regio-/ stereoisomers [43]. NMR analysis assisted the identification of various isomeric isoxazoline-linked chlorin products. Here, we would like to report an artificial vinylporphyrin 2, which has been designed to control the regioselectivity and reaction trajectory of the 1,3-dipolar cycloaddition reaction by steric hindrance. The obtained novel isoxazoline-substituted porphyrin derivatives 3a,b have been characterized by absorption, emission, NMR and mass spectrometry. In addition, the crystal structure of $\mathbf{3 a}$ is discussed.

\section{Results and Discussion}

The synthetic route to the $\beta$-isoxazoline-substituted porphyrin is depicted in Scheme 1, in which the double bond was furnished by Wittig reaction, followed by 1,3-dipolar cycloaddition reaction with stable dipoles. In detail, tetraphenylporphyrin (TPP) was used as starting material. A Vilsmeier reaction was carried out after insertion of $\mathrm{Cu}^{2+}$ into the cavity of TPP. In the presence of concentrated $\mathrm{H}_{2} \mathrm{SO}_{4}$ the $\mathrm{Cu}^{2+}$ was removed to give the 2-formyl derivative TPP-CHO. Subsequently, the formyl group was reduced by $\mathrm{NaBH}_{4}$, accompanied with chlorination by $\mathrm{SOCl}_{2}$, to afford the chloromethyl derivative TPP- $\mathrm{CH}_{2} \mathrm{Cl}$. Notably, this intermediate was labile on silica-gel column to give the precursor hydroxymethylporphyrin. Hence recrystallization was employed to purify it. Later, refluxing of the solution of TPP- $\mathrm{CH}_{2} \mathrm{Cl}$ and $\mathrm{PPh}_{3}$ in toluene gave the phosphonium salt 1 [44]. To introduce the vinyl group at the $\beta$-position, a Wittig reaction was performed, in which the porphyrin phosphonium salt 1 reacted with $4-\mathrm{MeCO}_{2}$-benzaldehyde in the presence of DBU to furnish the double bond, followed by insertion of $\mathrm{Zn}$ ions into the porphyrin cavity to give compound $\mathbf{2}$. Nitrile oxides [45] as one of the most reactive dipoles not only react with various dipolarophiles but also undergo spontaneous dimerization to form furoxans. To avoid or minimize this drawback, the substitutents (e.g., $\mathrm{Cl}$ or $\mathrm{Me}$ ) around the $\mathrm{CNO}$ group were introduced to stabilize the nitrile oxides even at room tem-

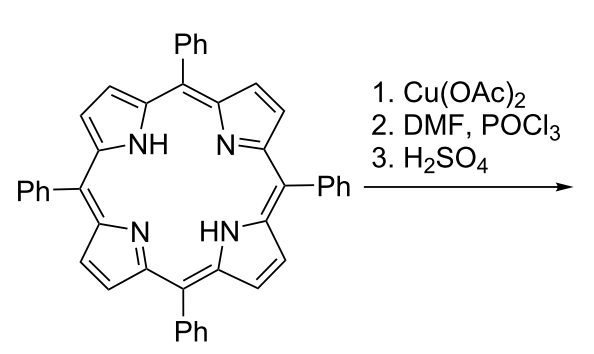

TPP

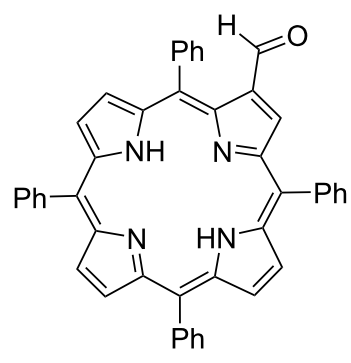

TPP-CHO

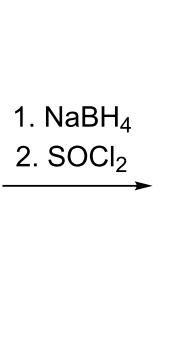

$\mathrm{NaBH}_{4}$

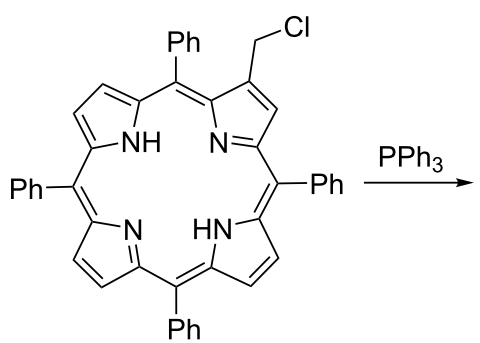

TPP- $-\mathrm{CH}_{2} \mathrm{Cl}$

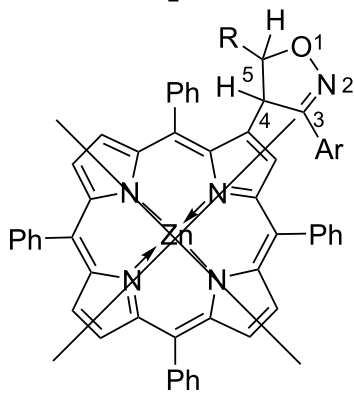

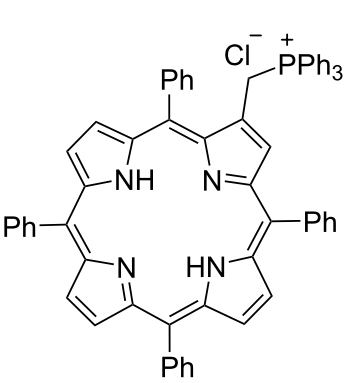

1
1. DBU,<smiles>CC(=O)c1ccc(C=O)cc1</smiles>

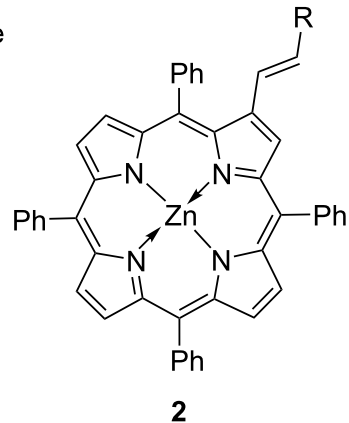

2

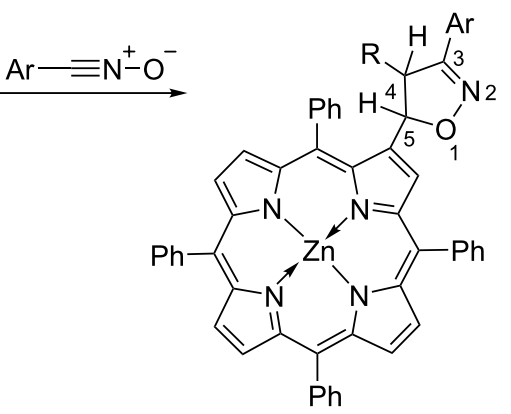

3a: $\mathrm{Ar}=2,6$-dichlorophenyl 3b: $\mathrm{Ar}=2,4,6$-trimethylphenyl 
perature $[46,47]$. Here, the 2,6-dichlorophenyl- or 2,4,6-trimethylphenyl nitrile oxides were used to react with 2 at $110^{\circ} \mathrm{C}$ for 12 hours in toluene. Generally, two products with different positions ( $\mathrm{C} 4$ or $\mathrm{C} 5)$ of isoxazoline connected to the $\beta$-position of porphyrin should be obtained if the stereochemistry was not considered (Scheme 1) [43]. However, only one fraction was isolated in this reaction besides the unconsumed starting material 2.

The structure of 1,3-dipole cycloaddition products $\mathbf{3 a}, \mathbf{b}$ were firstly characterized by absorption spectroscopy (Figure 1). The two compounds 3a,b showed approximately overlapped traces with typical intense Soret band and two weak Q bands. When compared to the spectrum of the precursor 2, a blue shift of $\approx 10 \mathrm{~nm}$ was observed in those of $\mathbf{3 a}$ or $\mathbf{3 b}$, which may result from the loss of partial conjugation after the cycloaddition reaction between the nitrile oxides and $\mathrm{C}=\mathrm{C}$ double bond. However, the substitution at the $\beta$-position in $\mathbf{3 a}$ or $\mathbf{3 b}$ led to $\mathbf{a} \approx 5 \mathrm{~nm}$ red shift when compared with the absorption spectrum of ZnTPP [48]. In addition, the fluorescence spectra of $\mathbf{3 a}$ and $\mathbf{3} \mathbf{b}$ were comparable with that of ZnTPP, and again shifted to short wavelength $(\approx 14 \mathrm{~nm})$ with respect to that of 2 . Later the ESIMS spectrum confirmed the constitution of two compounds, respectively. The pseudo molecular ions were observed at $\mathrm{m} / \mathrm{z}=$ 1024.1765, demonstrating the molecular formula of $\mathrm{C}_{61} \mathrm{H}_{39} \mathrm{Cl}_{2} \mathrm{~N}_{5} \mathrm{O}_{3} \mathrm{Zn}$ for $\mathbf{3 a}$, and $m / z=998.3011$, indicating the molecular formula of $\mathrm{C}_{64} \mathrm{H}_{47} \mathrm{~N}_{5} \mathrm{O}_{3} \mathrm{Zn}$ for $\mathbf{3 b}$. Thus, the formal formulas of $\mathbf{3 a}, \mathbf{b}$ are the sum of porphyrin $\mathbf{2}$ and the corresponding nitrile oxides.

Subsequently, the analysis of the ${ }^{1} \mathrm{H}$ NMR spectra helped to establish the structure of compound 3a,b (Figure 2). In the ${ }^{1} \mathrm{H}$ NMR spectrum of $\mathbf{2}$, the signals of the vinyl group were observed at $7.15 \mathrm{ppm}(J=16.0 \mathrm{~Hz})$ and $7.28 \mathrm{ppm}(J=16.0 \mathrm{~Hz}$, Figure 2, top), indicating a trans-configuration of the double bond. The signal of the $\mathrm{CO}_{2} \mathrm{Me}$ group occurred at $3.93 \mathrm{ppm}$, while those of the $\beta$-pyrrolic protons were in the range of $8.82 \mathrm{ppm}$ to $9.13 \mathrm{ppm}$.

As consequence of the cycloaddition reaction, the signals of the vinyl group vanished in the spectra of $\mathbf{3 a}$ or $\mathbf{3} \mathbf{b}$. Taking the analysis of 3a as example. Two doublets at $5.07 \mathrm{ppm}$ $(J=4.0 \mathrm{~Hz})$ and $6.15 \mathrm{ppm}(J=4.0 \mathrm{~Hz})$ aroused, which should be assigned to the two saturated $\mathrm{CHs}$ after dipolar cycloaddition reaction between the vinyl group and dichlorophenyl nitrile oxides. A multiplet was observed around $7.13 \mathrm{ppm}$ and assigned to the aromatic protons of the 2,6-dichlorophenyl group. Meanwhile the aromatic signals of $\mathrm{C}_{6} \mathrm{H}_{4} \mathrm{CO}_{2} \mathrm{Me}$ shifted to the higher field when compared to that of 2 , owing to the disturbing of the de-shielding effect from the double bond and porphyrin framework. Similar variation was also realized in the spectrum of $\mathbf{3 b}$. Based on these, the cycloaddition reaction should take place on the $\beta$-vinyl group but not the double bond on the porphyrin framework, indicating the high activity of the $\beta$-vinyl group over the double bond on the macrocycle. However, at which position of the newly formed isoxazoline is linked to the porphyrin is still elusive.

Later, a single crystal of 3a was obtained by diffusion of $n$-hexane to the solution of $\mathbf{3 a}$ in $\mathrm{CHCl}_{3}$ at $23{ }^{\circ} \mathrm{C}$. The structure of 3a was unambiguously established by single-crystal X-ray diffraction analysis. Compound 3a crystallized in the monoclinic with space group $C 2 / c$. Figure 3 shows the dimeric structure of 3a (front view and side view). Notably, only the 5-position of isoxazoline linking to porphyrin was observed. As expected, the steric clash of the substituent on nitrile oxide and porphyrin framework seems to confine the reaction trajectory and direct nitrile oxide to approach the double bond from outside the macrocycle. In addition, a pair of enantiomers is revealed which formed a dimeric fashion with the help of the
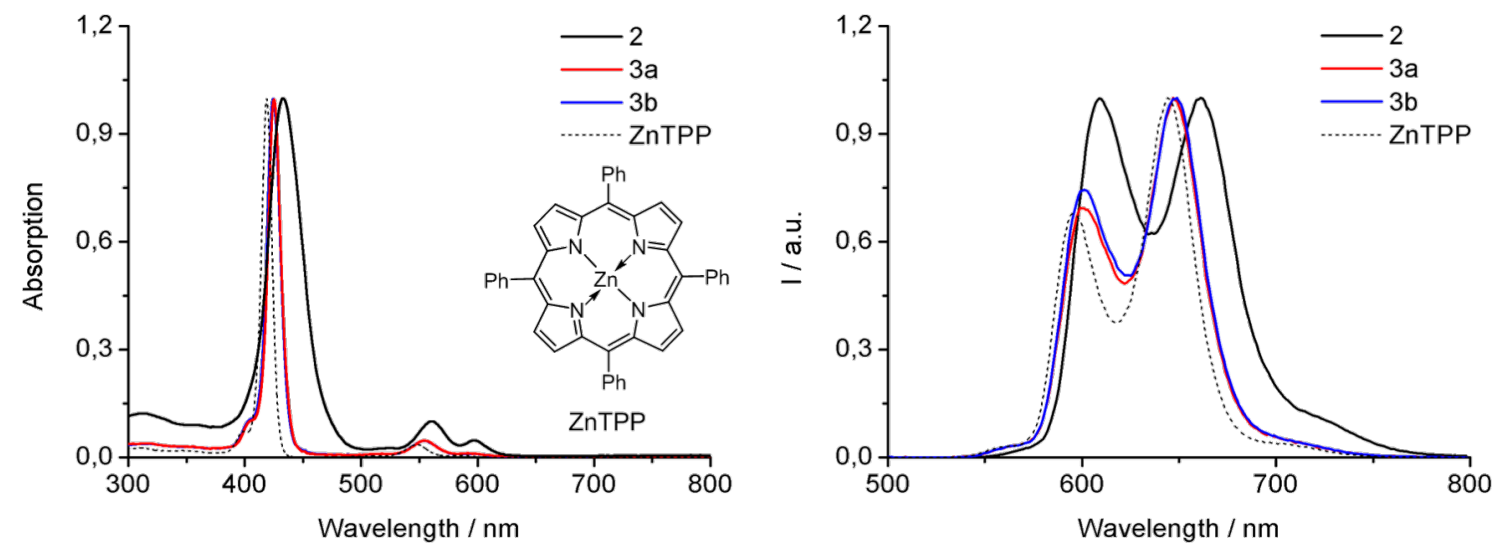

Figure 1: Normalized UV-vis and emission spectra of $\beta$-isoxazoline porphyrins $3 \mathbf{a}, \mathbf{b}, 2$ and $Z n T P P$ in $\mathrm{CH}_{2} \mathrm{Cl}_{2}$. 


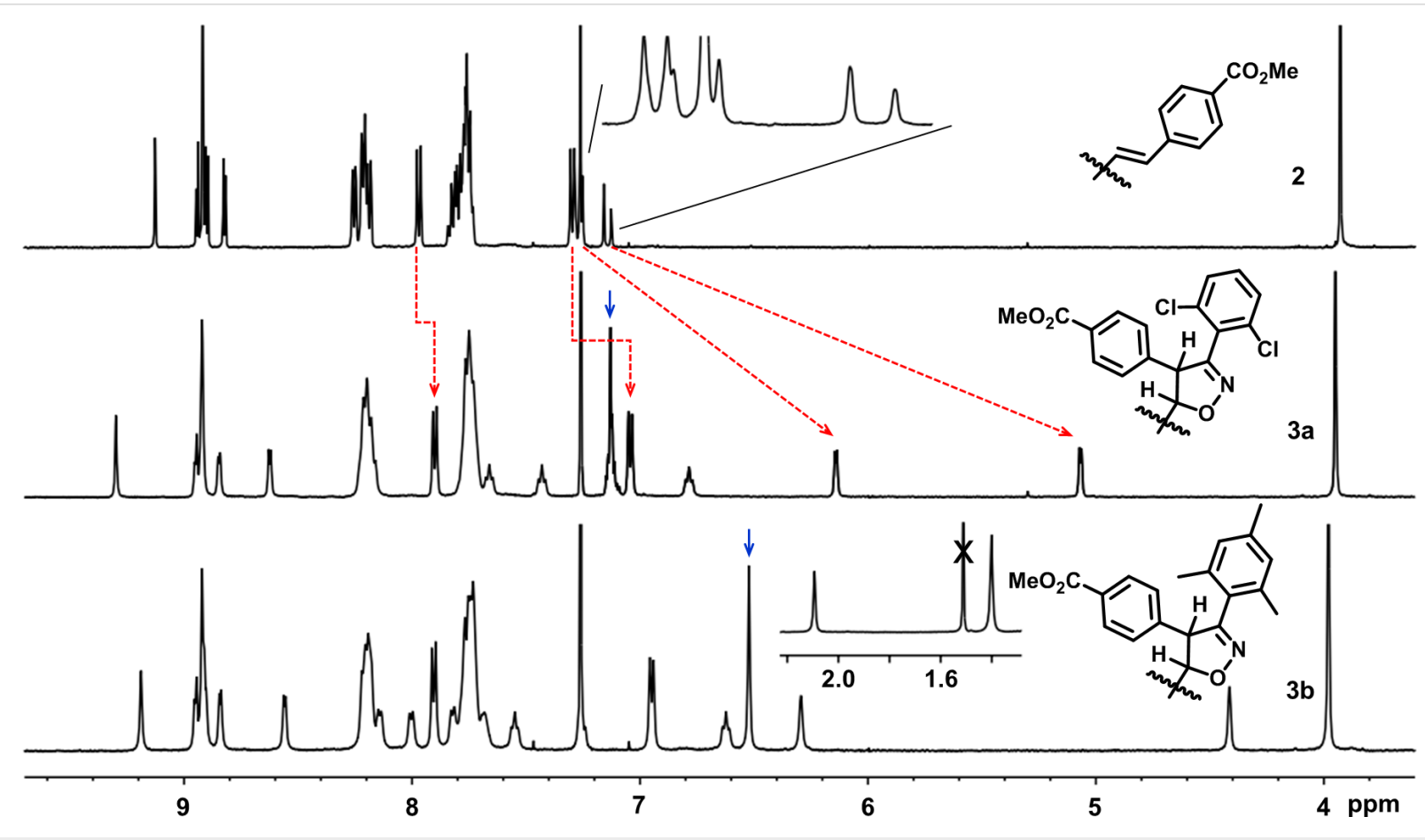

Figure 2: The ${ }^{1} \mathrm{H}$ NMR spectra of 2 (top, partially zoomed around $7.26 \mathrm{ppm}$ ), 3a (middle, red arrows indicate the high field shift of the protons after 1,3-diploar cycloaddition, while the blue one is the signal of aromatic protons of the dichlorophenyl group) and $\mathbf{3 b}$ (bottom, inset is the signal of $\mathrm{CH}_{3}$ around $2 \mathrm{ppm}, \mathrm{x}$ marks the signal of $\mathrm{H}_{2} \mathrm{O}$, the blue one is the signal of aromatic protons on trimethylphenyl group) in $\mathrm{CDCl}_{3}\left(500 \mathrm{MHz}, 25^{\circ} \mathrm{C}\right)$.

a)

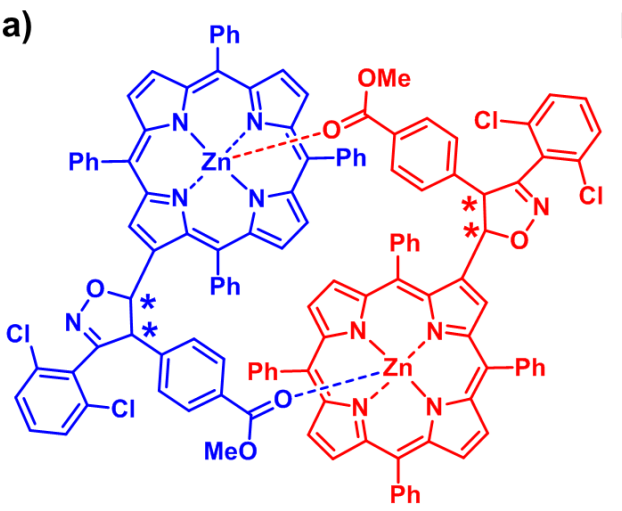

c)

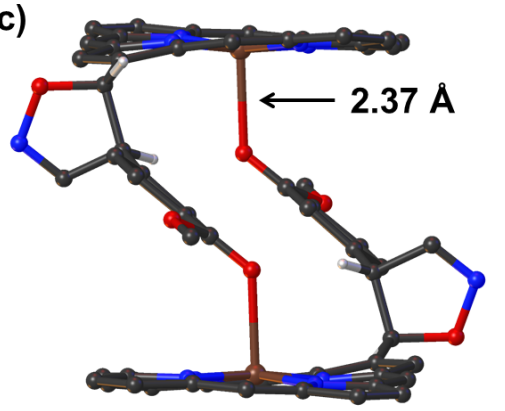

b)

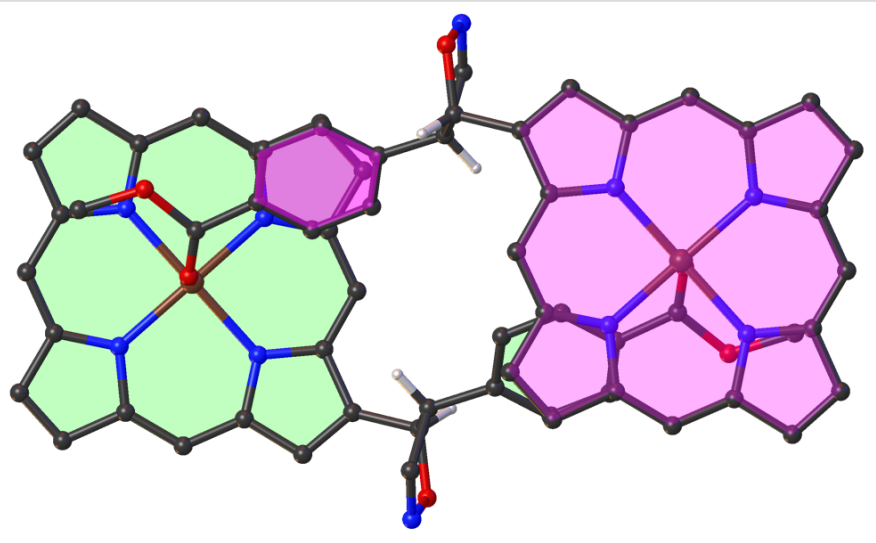

d)

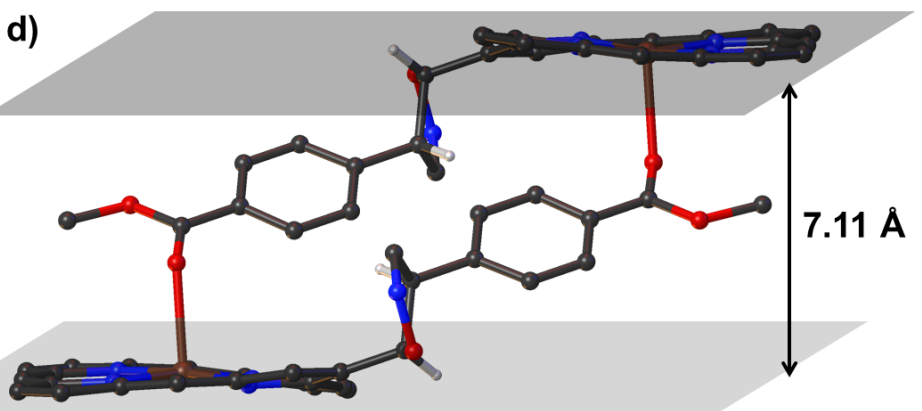

Figure 3: The representative dimeric structure of 3a according to the crystal structure (a) and enantiomeric dimer structure in crystal (b-d, the phenyl group at meso-positions and 2,6-dichlorophenyl group were omitted for the sake of clarity). The distances of $\mathrm{Zn}-\mathrm{O}$ (c) and distance between the two mean planes of porphyrins (d) has been labeled. 
fifth coordination to the $\mathrm{Zn}^{2+}$ by the carbonyl group from the other molecule. The distance of $\mathrm{Zn}-\mathrm{O}$ is found to be $2.37 \AA$, which is longer than the distance when $\mathrm{MeOH}$ coordinated to the $\mathrm{Zn}^{2+}$ ions [49]. This may attribute to the larger volume of the $\mathrm{C}_{6} \mathrm{H}_{4} \mathrm{CO}_{2} \mathrm{Me}$ group than $\mathrm{MeOH}$ when closing to the $\mathrm{Zn}^{2+}$ center. In the dimer structure, two planes defined by porphyrin macrocycles are parallel with a distance of $7.11 \AA$. The bulky substituent group around the $\beta$-position, in conjunction with the presence of four benzene rings attached to the central porphyrin core, twist the overall geometry of the molecule. For instance, the porphyrin core is slightly distorted with deviation of $0.14 \AA$. The dihedral angles ranges from $2.6^{\circ}$ to $8.7^{\circ}$ for the four pyrrole rings with respect to the porphyrin mean plane, which are more twisted than that in normal $\mathrm{Zn}$-porphyrin [49]. The lengths of $\mathrm{Zn}-\mathrm{N}$ bonds range from $2.041 \AA$ to $2.073 \AA$. The new formed five-membered isoxazoline ring is almost vertical (with a dihedral angle of $82.7^{\circ}$ ) to the mean plane of the porphyrin core. While the dihedral angle between the plane defined by macrocycle and the methoxycarbonylbenzene ring was found to be $40.5^{\circ}$.

\section{Conclusion}

In summary, two novel isoxazoline-substituted porphyrin derivatives 3a,b have been synthesized via the regiospecific and steric-oriented 1,3-dipolar cycloaddition reaction of vinylporphyrin 2 and two nitrile oxides, respectively. Only the product with a link between the 5-position of the isoxazoline and the $\beta$-position of porphyrin was obtained, directed by steric hindrance when the two components are approaching to each other. Owing to the interruption of the double bond after the cycloaddition reaction, the absorption spectrum shifted to shorter wavelengths. The isoxazoline-modified porphyrins have been identified by absorption, emission, ${ }^{1} \mathrm{H}$ NMR and mass spectrometry, and 3a was further characterized by X-ray analysis. In the crystal, a pair of enantiomers of $\mathbf{3 a}$ is present, which assembled to a dimeric structure with the fifth chelation of a $\mathrm{Zn}^{2+}$ ion by the carbonyl group of the other molecule. The selfdimerization property of 3a may be utilized in supramolecular chemistry [50-53].

\section{Experimental}

1: Porphyrin phosphonium salt $\mathbf{1}$ was prepared according to the literature [44], the yield was $51 \% .{ }^{1} \mathrm{H} \mathrm{NMR}\left(500 \mathrm{MHz}, \mathrm{CDCl}_{3}\right)$ $\delta-2.77$ (s, 2H, inner $\mathrm{NH}), 5.19-5.22(\mathrm{~d}, J=15.0 \mathrm{~Hz}, 2 \mathrm{H}$, $\left.\mathrm{CH}_{2} \mathrm{P}\right), 7.10-7.14(\mathrm{~m}, 6 \mathrm{H}), 7.27-7.30(\mathrm{~m}, 5 \mathrm{H}), 7.39(\mathrm{~d}, J=$ $10.0 \mathrm{~Hz}, 2 \mathrm{H}), 7.40-7.89(\mathrm{~m}, 18 \mathrm{H}), 8.17-8.19(\mathrm{~m}, 4 \mathrm{H}), 8.31(\mathrm{~d}$ $J=4.0 \mathrm{~Hz}, 1 \mathrm{H}, \beta$-pyrrolic $\mathrm{H}), 8.46(\mathrm{~d}, J=4.0 \mathrm{~Hz}, 1 \mathrm{H}$, $\beta$-pyrrolic H), 8.76-8.86 ( $\mathrm{m}, 5 \mathrm{H}, \beta$-pyrrolic H).

2: To the solution of compound $\mathbf{1}(0.10 \mathrm{~g}, 0.11 \mathrm{mmol})$ and 4-methoxycarbonylbenzaldehyde $(18 \mathrm{mg}, 0.11 \mathrm{mmol})$ in
$\mathrm{CH}_{2} \mathrm{Cl}_{2}(20 \mathrm{~mL})$ was added DBU ( $83 \mathrm{mg}, 0.55 \mathrm{mmol}, 5.0$ equiv vs 1 ). The reaction mixture was stirred for 8 hours. $\mathrm{H}_{2} \mathrm{O}$ $(15 \mathrm{~mL})$ was added to quench the reaction. The organic phase was separated and dried with $\mathrm{MgSO}_{4}$, followed by filtration and concentration to obtain a dark red residue. The product was isolated as first fraction by silica gel column chromatography with an eluent consisting of $\mathrm{CH}_{2} \mathrm{Cl}_{2}$ /petrol ether 1:1 (v:v). Finally, the free-base porphyrin $\mathbf{2}-\mathbf{H}_{2}$ was obtained in a yield of $68 \mathrm{mg}$ $(82 \%)$. The obtained free-base porphyrin $\mathbf{2}-\mathbf{H}_{\mathbf{2}}(50 \mathrm{mg}$, $0.065 \mathrm{mmol})$ was dissolved in $\mathrm{CHCl}_{3}(20 \mathrm{~mL})$. Then the solution of $\mathrm{Zn}(\mathrm{OAc})_{2} \cdot 2 \mathrm{H}_{2} \mathrm{O}(28.5 \mathrm{mg}, 0.13 \mathrm{mmol}, 2$ equiv) in $\mathrm{MeOH}(6 \mathrm{~mL})$. After 2 hours, TLC analysis showed the completion of the reaction. $\mathrm{H}_{2} \mathrm{O}$ was added to quench the reaction and the organic phase was collected. Then the organic phase was dried by $\mathrm{MgSO}_{4}$, followed by filtration and concentration under reduced pressure. The raw product was purified by silica gel column chromatography with eluent of $\mathrm{CH}_{2} \mathrm{Cl}_{2} /$ petrol ether 3:1 (v:v). Finally, compound 2 was obtained in a yield of 92\% (50.2 mg). ${ }^{1} \mathrm{H}$ NMR (500 MHz, $\mathrm{CDCl}_{3}$ ) $\delta 3.93$ (s, 3H, $\left.\mathrm{CO}_{2} \mathrm{CH}_{3}\right), 7.15(\mathrm{~d}, J=16.0 \mathrm{~Hz}, 1 \mathrm{H}, \mathrm{CH}=\mathrm{CH}), 7.28(\mathrm{~d}, J=$ $16.0 \mathrm{~Hz}, 1 \mathrm{H}, \mathrm{CH}=\mathrm{CH}), 7.30(\mathrm{~d}, J=8.0 \mathrm{~Hz}, 2 \mathrm{H}), 7.75-7.85(\mathrm{~m}$, $12 \mathrm{H}), 7.97(\mathrm{~d}, J=8.0 \mathrm{~Hz}, 2 \mathrm{H}), 8.18-8.22(\mathrm{~m}, 6 \mathrm{H}), 8.24-8.26$ $(\mathrm{m}, 2 \mathrm{H}), 8.83(\mathrm{~d}, J=4.0 \mathrm{~Hz}, 1 \mathrm{H}, \beta$-pyrrolic $\mathrm{H}), 8.90$ (d, $J=4.0 \mathrm{~Hz}, 1 \mathrm{H}, \beta$-pyrrolic $\mathrm{H}), 8.91-8.92$ (m, 3H, $\beta$-pyrrolic $\mathrm{H}$ ), $8.94(\mathrm{~d}, J=4.0 \mathrm{~Hz}, 1 \mathrm{H}, \beta$-pyrrolic H), 9.13 (s, 1H, $\beta$-pyrrolic $\mathrm{H})$; ESIMS $m / z$ : $[\mathrm{M}+\mathrm{H}]^{+}$calcd for $\mathrm{C}_{54} \mathrm{H}_{39} \mathrm{~N}_{4} \mathrm{O}_{2} \mathrm{ZnF}$, 837.2; found, 837.1; UV-vis $\left(\mathrm{CH}_{2} \mathrm{Cl}_{2}\right) \lambda_{\max }: 432,561,597 \mathrm{~nm}$.

3a: A solution of $2(100 \mathrm{mg}, 0.12 \mathrm{mmol})$ and nitrile oxide $(0.6 \mathrm{mmol}, 5$ equiv) in dry toluene $(20 \mathrm{~mL})$ was heated to reflux for 6 hours under $\mathrm{N}_{2}$. Subsequently, addition of two portions of 2,6-dichlorophenyl nitrile oxide [45] $(0.3 \mathrm{mmol})$ were added to the reaction mixture every 3 hours. The reaction mixture was concentrated to dryness under reduced pressure and the product was isolated by silica gel column chromatography with eluent of DCM/ethyl acetate 50:1 (v/v). The second purple fraction was collected. Finally, 3a was obtained in a yield of $48 \%$ $(59 \mathrm{mg})$ as purple powder. ${ }^{1} \mathrm{H} \mathrm{NMR}\left(500 \mathrm{MHz}, \mathrm{CDCl}_{3}\right) \delta 3.95$ $\left(\mathrm{s}, 3 \mathrm{H}, \mathrm{CO}_{2} \mathrm{CH}_{3}\right), 5.07(\mathrm{~d}, J=4.0 \mathrm{~Hz}, 1 \mathrm{H}, \mathrm{CH}), 6.15(\mathrm{~d}$, $J=4.0 \mathrm{~Hz}, 1 \mathrm{H}, \mathrm{CH}), 6.79(\mathrm{t}, J=6.0 \mathrm{~Hz}, 1 \mathrm{H}), 7.05(\mathrm{~d}, J=$ $8.0 \mathrm{~Hz}, 2 \mathrm{H}), 7.12-7.15(\mathrm{~m}, 3 \mathrm{H}), 7.44(\mathrm{t}, J=6.0 \mathrm{~Hz}, 1 \mathrm{H}), 7.67$ (t, $J=6.0 \mathrm{~Hz}, 1 \mathrm{H}), 7.76-7.77(\mathrm{~m}, 10 \mathrm{H}), 7.91(\mathrm{~d}, J=8.0 \mathrm{~Hz}$, 2H), 8.17-8.22 (m, 7H), 8.63 (d, $J=4.0 \mathrm{~Hz}, 1 \mathrm{H}, \beta$-pyrrolic H), $8.85(\mathrm{~d}, J=4.0 \mathrm{~Hz}, 1 \mathrm{H}, \beta$-pyrrolic $\mathrm{H}), 8.92-8.95(\mathrm{~m}, 4 \mathrm{H}$, $\beta$-pyrrolic H), 9.30 (s, $1 \mathrm{H}, \beta$-pyrrolic H). ESIMS $m / z$ : $[\mathrm{M}+\mathrm{H}]^{+}$ calcd for $\mathrm{C}_{61} \mathrm{H}_{40} \mathrm{Cl}_{2} \mathrm{~N}_{5} \mathrm{O}_{3} \mathrm{Zn}, 1024.1794$; found, 1024.1765; UV-vis $\left(\mathrm{CH}_{2} \mathrm{Cl}_{2}\right) \lambda_{\max }: 403,424,552,592 \mathrm{~nm}$. Some crystals of $\mathrm{C}_{61} \mathrm{H}_{39} \mathrm{Cl}_{2} \mathrm{~N}_{5} \mathrm{O}_{3} \mathrm{Zn}$ were recrystallized from $\mathrm{CHCl}_{3}$ / $n$-hexane. A suitable crystal was selected and mounted on a Rigaku Saturn CCD area detector diffractometer. The crystal was kept at $113 \mathrm{~K}$ during data collection. Using Olex2 [54], the 
structure was solved with the XS [55] structure solution program using Direct Methods and refined with the olex2.refine [56] refinement package using Gauss-Newton minimisation. Crystal data for $\mathrm{C}_{61} \mathrm{H}_{39} \mathrm{Cl}_{2} \mathrm{~N}_{5} \mathrm{O}_{3} \mathrm{Zn}(M=1026.32 \mathrm{~g} / \mathrm{mol})$ : monoclinic, space group $C 2 / c$ (no. 15), $a=28.166(6) \AA, b=$ 17.330(4) $\AA, c=26.363(5) \AA, \beta=117.96(3)^{\circ}, V=11366(5) \AA^{3}$, $Z=8, T=113 \mathrm{~K}, \mu(\mathrm{Mo} \mathrm{K} \alpha)=0.573 \mathrm{~mm}^{-1}$, Dcalc $=1.1995 \mathrm{~g} /$ $\mathrm{cm}^{3}, 40330$ reflections measured $\left(4.7^{\circ} \leq 2 \Theta \leq 50.04^{\circ}\right), 9924$ unique $\left(R_{\text {int }}=0.0578, \mathrm{R}_{\text {sigma }}=0.0601\right)$ which were used in all calculations. The final $R_{1}$ was $0.0861(\mathrm{I}>=2 \mathrm{u}(\mathrm{I}))$ and $w R_{2}$ was 0.2556 (all data). The CCDC number of the crystal of $\mathbf{3 a}$ is 1910675, which can be obtained free of charge from the Cambridge Crystallographic Data Centre via http:// www.ccdc.cam.ac.uk/data_request/cif.

3b: Through the same procedure as that for $\mathbf{3 a}$, besides using 2,4,6-trimethylphenyl nitrile oxide [45], compound $\mathbf{3 b}$ was obtained in a yield of $30 \%(36 \mathrm{mg}) .{ }^{1} \mathrm{H} \mathrm{NMR}\left(500 \mathrm{MHz}, \mathrm{CDCl}_{3}\right)$ $\delta 1.40\left(\mathrm{~s}, 6 \mathrm{H}, \mathrm{CH}_{3}\right), 2.09\left(\mathrm{~s}, 3 \mathrm{H}, \mathrm{CH}_{3}\right), 3.98\left(\mathrm{~s}, 3 \mathrm{H}, \mathrm{CO}_{2} \mathrm{CH}_{3}\right)$, $4.42(\mathrm{~s}, 1 \mathrm{H}, \mathrm{C}-\mathrm{H}), 6.29(\mathrm{~s}, 1 \mathrm{H}, \mathrm{CH}), 6.52(\mathrm{~s}, 2 \mathrm{H}), 6.62(\mathrm{t}, J=$ $6.0 \mathrm{~Hz}, 1 \mathrm{H}), 6.95(\mathrm{~d}, J=7.5 \mathrm{~Hz}, 2 \mathrm{H}), 7.55(\mathrm{t}, J=6.0 \mathrm{~Hz}, 1 \mathrm{H})$, $7.69-7.77(\mathrm{~m}, 10 \mathrm{H}), 7.82(\mathrm{~d}, J=7.0 \mathrm{~Hz}, 2 \mathrm{H}), 7.91(\mathrm{~d}, J=$ $7.5 \mathrm{~Hz}, 2 \mathrm{H}), 8.00(\mathrm{~d}, J=7.0 \mathrm{~Hz}, 1 \mathrm{H}), 8.56(\mathrm{~d}, J=7.0 \mathrm{~Hz}, 1 \mathrm{H})$, 8.16-8.22 (m, 5H), 8.56 (d, $J=4.0 \mathrm{~Hz}, 1 \mathrm{H}, \beta$-pyrrolic $\mathrm{H}), 8.84$ (d, $J=4.0 \mathrm{~Hz}, 1 \mathrm{H}, \beta$-pyrrolic H), 8.90-8.92 (m, 3H, $\beta$-pyrrolic $\mathrm{H}), 8.95(\mathrm{~d}, J=4.0 \mathrm{~Hz}, 1 \mathrm{H}, \beta$-pyrrolic $\mathrm{H}), 9.19(\mathrm{~s}, 1 \mathrm{H}$, $\beta$-pyrrolic $\mathrm{H}$ ); ESIMS $m / z$ : $[\mathrm{M}+\mathrm{H}]^{+}$calcd for $\mathrm{C}_{64} \mathrm{H}_{48} \mathrm{~N}_{5} \mathrm{O}_{3} \mathrm{Zn}$, 998.3043; found, 998.3011; UV-vis $\left(\mathrm{CH}_{2} \mathrm{Cl}_{2}\right) \lambda_{\max }$ : 402, 424, $552,595 \mathrm{~nm}$.

ZnTPP: The Zn-complex of TPP was prepared according to the literature [48], the yield was $89 \% .{ }^{1} \mathrm{H} \mathrm{NMR}\left(500 \mathrm{MHz}, \mathrm{CDCl}_{3}\right)$

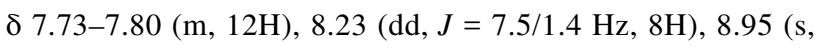
$8 \mathrm{H}, \beta$-pyrrolic $\mathrm{H})$.

\section{Supporting Information}

\section{Supporting Information File 1}

$\mathrm{X}$-ray data of compound 3a.

[https://www.beilstein-journals.org/bjoc/content/ supplementary/1860-5397-15-143-S1.cif]

\section{Acknowledgements}

The work is supported by National Natural Science Foundation of China (No. 21761132007, 21722603 and 21871083).

\section{ORCID ${ }^{\circledR}$ iDs}

Xiujun Liu - https://orcid.org/0000-0002-1858-2331 Xiang Ma - https://orcid.org/0000-0002-8679-4491 Yaqing Feng - https://orcid.org/0000-0001-7763-7470

\section{References}

1. Battersby, A. R. Nat. Prod. Rep. 2000, 17, 507-526. doi:10.1039/b002635m

2. Kraeutler, B. Chimia 1987, 41, 277-292. doi:10.2524/jtappij.41.3_292

3. Eschenmoser, A. Angew. Chem., Int. Ed. Engl. 1988, 27, 5-39. doi:10.1002/anie.198800051

4. Severance, S.; Hamza, I. Chem. Rev. 2009, 109, 4596-4616. doi:10.1021/cr9001116

5. Maxwell, K.; Johnson, G. N. J. Exp. Bot. 2000, 51, 659-668. doi:10.1093/jxb/51.345.659

6. Ding, Y.; Zhu, W.-H.; Xie, Y. Chem. Rev. 2017, 117, 2203-2256. doi:10.1021/acs.chemrev.6b00021

7. Zhang, W.; Lai, W.; Cao, R. Chem. Rev. 2017, 117, 3717-3797. doi:10.1021/acs.chemrev.6b00299

8. Paolesse, R.; Nardis, S.; Monti, D.; Stefanelli, M.; Di Natale, C. Chem. Rev. 2017, 117, 2517-2583. doi:10.1021/acs.chemrev.6b00361

9. Baglia, R. A.; Zaragoza, J. P. T.; Goldberg, D. P. Chem. Rev. 2017, 117, 13320-13352. doi:10.1021/acs.chemrev.7b00180

10. Lu, H.; Kobayashi, N. Chem. Rev. 2016, 116, 6184-6261. doi:10.1021/acs.chemrev.5b00588

11. Rajora, M. A.; Lou, J. W. H.; Zheng, G. Chem. Soc. Rev. 2017, 46, 6433-6469. doi:10.1039/c7cs00525c

12. Thompson, S. J.; Brennan, M. R.; Lee, S. Y.; Dong, G. Chem. Soc. Rev. 2018, 47, 929-981. doi:10.1039/c7cs00582b

13. Tanaka, T.; Osuka, A. Chem. Soc. Rev. 2015, 44, 943-969. doi:10.1039/c3cs60443h

14. Li, L.-L.; Diau, E. W.-G. Chem. Soc. Rev. 2013, 42, 291-304. doi:10.1039/c2cs35257e

15. Szyszko, B.; Latos-Grażyński, L. Chem. Soc. Rev. 2015, 44, 3588-3616. doi:10.1039/c4cs00398e

16. Chatterjee, T.; Shetti, V. S.; Sharma, R.; Ravikanth, M. Chem. Rev. 2017, 117, 3254-3328. doi:10.1021/acs.chemrev.6b00496

17. Hiroto, S.; Miyake, Y.; Shinokubo, H. Chem. Rev. 2017, 117, 2910-3043. doi:10.1021/acs.chemrev.6b00427

18. Lash, T. D. Chem. Rev. 2017, 117, 2313-2446. doi:10.1021/acs.chemrev.6b00326

19. Matano, Y. Chem. Rev. 2017, 117, 3138-3191. doi:10.1021/acs.chemrev.6b00460

20. Sarma, T.; Panda, P. K. Chem. Rev. 2017, 117, 2785-2838. doi:10.1021/acs.chemrev.6b00411

21. Anguera, G.; Sánchez-García, D. Chem. Rev. 2017, 117, 2481-2516. doi:10.1021/acs.chemrev.6b00345

22. Tanaka, T.; Osuka, A. Chem. Rev. 2017, 117, 2584-2640. doi:10.1021/acs.chemrev.6b00371

23. Taniguchi, M.; Lindsey, J. S. Chem. Rev. 2017, 117, 344-535. doi:10.1021/acs.chemrev.5b00696

24. Li, Q.; Li, C.; Kim, J.; Ishida, M.; Li, X.; Gu, T.; Liang, X.; Zhu, W.; Ågren, H.; Kim, D.; Furuta, H.; Xie, Y. J. Am. Chem. Soc. 2019, 141, 5294-5302. doi:10.1021/jacs.8b13148

25. Huisgen, R. Angew. Chem., Int. Ed. Engl. 1963, 2, 565-598. doi:10.1002/anie.196305651

26. Gałezowski, M.; Gryko, D. T. J. Org. Chem. 2006, 71, 5942-5950. doi:10.1021/jo060545x

27. Liu, X.; Feng, Y.; Hu, X.; Li, X. Synthesis 2005, 3632-3638. doi:10.1055/s-2005-918415

28. Liu, X.; Feng, Y.; Chen, X.; Li, F.; Li, X. Synlett 2005, 1030-1032. doi:10.1055/s-2005-864811

29. Li, X.; Zhuang, J.; Li, Y.; Liu, H.; Wang, S.; Zhu, D. Tetrahedron Lett. 2005, 46, 1555-1559. doi:10.1016/j.tetlet.2004.12.138 
30. Almeida, J.; Aguiar, A.; Leite, A.; Silva, A. M. N.; Cunha-Silva, L.; de Castro, B.; Rangel, M.; Barone, G.; Tomé, A. C.; Silva, A. M. G. Org. Chem. Front. 2017, 4, 534-544. doi:10.1039/c6qo00771f

31. Wyrębek, P.; Mikus, A.; Ostrowski, S. Heterocycles 2012, 85, 57-64. doi:10.3987/com-11-12347

32. Tomé, A. C.; Neves, M. G. P. M. S.; Cavaleiro, J. A. S. J. Porphyrins Phthalocyanines 2009, 13, 408-414. doi:10.1142/s1088424609000619

33. Ostrowski, S.; Wyrebek, P.; Mikus, A. Heterocycles 2006, 68, 885-888. doi:10.3987/com-06-10691

34. Silva, A. M. G.; Tomé, A. C.; Neves, M. G. P. M. S.; Silva, A. M. S.; Cavaleiro, J. A. S.; Perrone, D.; Dondoni, A. Tetrahedron Lett. 2002, 43, 603-605. doi:10.1016/s0040-4039(01)02243-2

35. Silva, A. M. G.; Tomé,, A. C.; Neves, M. G. P. M. S.; Silva, A. M. S.; Cavaleiro, J. A. S. J. Org. Chem. 2005, 70, 2306-2314. doi:10.1021/jo048349i

36. Séverac, M.; Pleux, L. L.; Scarpaci, A.; Blart, E.; Odobel, F. Tetrahedron Lett. 2007, 48, 6518-6522. doi:10.1016/j.tetlet.2007.07.049

37. Flemming, J.; Dolphin, D. Tetrahedron Lett. 2002, 43, 7281-7283. doi:10.1016/s0040-4039(02)01619-2

38. Jäger, V.; Grund, H.; Buß, V.; Schwab, W.; Müller, I.; Schohe, R.; Franz, R.; Ehrler, R. Bull. Soc. Chim. Belg. 1983, 92, 1039-1054. doi:10.1002/bscb.19830921113

39. Evans, D. A.; Ripin, D. H. B.; Halstead, D. P.; Campos, K. R. J. Am. Chem. Soc. 1999, 121, 6816-6826. doi:10.1021/ja990789h

40. Habeeb, A. G.; Praveen Rao, P. N.; Knaus, E. E. J. Med. Chem. 2001, 44, 2921-2927. doi:10.1021/jm0101287

41. Habeeb, A. G.; Rao, P. N. P.; Knaus, E. E. Drug Dev. Res. 2000, 51, 273-286. doi:10.1002/ddr.9

42. da Silva, A. F. F.; Barata, J. F. B.; Silva, A. M. G.; Neves, M. G. P. M. S.; Tomé, A. C.; Silva, A. M. S.; Cavaleiro, J. A. S. Tetrahedron Lett. 2015, 56, 2878-2881. doi:10.1016/j.tetlet.2015.04.066

43. Wang, J.-J.; Li, J.-Z.; Li, Y.-W.; Jakus, J.; Shim, Y. K. J. Porphyrins Phthalocyanines 2010, 14, 859-865. doi:10.1142/s1088424610002690

44. Bonfantini, E. E.; Officer, D. L. Tetrahedron Lett. 1993, 34, 8531-8534. doi:10.1016/s0040-4039(00)61377-1

45. Grundmann, C. Angew. Chem., Int. Ed. Engl. 1963, 2, 260-261. doi:10.1002/anie.196302601

46. Grundmann, C.; Dean, J. M. J. Org. Chem. 1965, 30, 2809-2812. doi:10.1021/jo01019a074

47. Grundmann, C.; Dean, J. M. Angew. Chem., Int. Ed. Engl. 1964, 3 , 585-586. doi:10.1002/anie.196405852

48. Vail, S. A.; Schuster, D. I.; Guldi, D. M.; Isosomppi, M.; Tkachenko, N.; Lemmetyinen, H.; Palkar, A.; Echegoyen, L.; Chen, X.; Zhang, J. Z. H. J. Phys. Chem. B 2006, 110, 14155-14166. doi:10.1021/jp061844t

49. Banala, S.; Wurst, K.; Kräutler, B. J. Porphyrins Phthalocyanines 2014, 18, 115-122. doi:10.1142/s1088424613501204

50. Zhang, W.; Li, G.; Xu, L.; Zhuo, Y.; Wan, W.; Yan, N.; He, G. Chem. Sci. 2018, 9, 4444-4450. doi:10.1039/c8sc00688a

51. Jiang, T.; Wang, X.; Wang, J.; Hu, G.; Ma, X. ACS Appl. Mater. Interfaces 2019, 11, 14399-14407. doi:10.1021/acsami.9b03112

52. Xu, C.; Xu, L.; Ma, X. Chin. Chem. Lett. 2018, 29, 970-972. doi:10.1016/j.cclet.2017.11.045

53. Li, D.; Wang, J.; Ma, X. Adv. Opt. Mater. 2018, 6, 1800273. doi:10.1002/adom.201800273
54. Dolomanov, O. V.; Bourhis, L. J.; Gildea, R. J.; Howard, J. A. K.; Puschmann, H. J. Appl. Crystallogr. 2009, 42, 339-341. doi:10.1107/s0021889808042726

55. Sheldrick, G. M. Acta Crystallogr., Sect. A: Found. Crystallogr. 2008, 64, 112-122. doi:10.1107/s0108767307043930

56. Bourhis, L. J.; Dolomanov, O. V.; Gildea, R. J.; Howard, J. A. K.; Puschmann, H. Acta Crystallogr., Sect. A: Found. Adv. 2015, 71, 59-75. doi:10.1107/s2053273314022207

\section{License and Terms}

This is an Open Access article under the terms of the Creative Commons Attribution License

(http://creativecommons.org/licenses/by/4.0). Please note that the reuse, redistribution and reproduction in particular requires that the authors and source are credited.

The license is subject to the Beilstein Journal of Organic Chemistry terms and conditions: (https://www.beilstein-journals.org/bjoc)

The definitive version of this article is the electronic one which can be found at: doi:10.3762/bjoc. 15.143 